Jurnal Kejaora: Jurnal Kesehatan Jasmani dan Olah Raga

ISSN: 2541-5042 (Online)

ISSN: 2503-2976 (Print)

Volume 5 Nomor 2, Edisi November 2020

\title{
PENGARUH WAKTU PEMBELAJARAN PENDIDIKAN JASMANI OLAHRAGA DAN KESEHATAN (PJOK) TERHADAP TINGKAT KEBUGARAN SISWA KELAS V MI BAHRUL ULUM SUKODONO SIDOARJO
}

\author{
Adjie Mas Achmad Nur Aulia Arifaen ${ }^{1}$, Harwanto², Hari Karyono³
}

1,2,3Pascasarjana UNIPA Surabaya

E-mail: adjiemasachmad@gmail.com1, harwanto@unipasby.ac.id², harikaryono@yahoo.com³

DOI: https://doi.org/10.36526/kejaora.v5i2.1043

\begin{abstract}
ABSTRAK
Penelitian ini bertujuan untuk mengetahui pengaruh pemberian waktu pembelajaran pendidikan jasmani olahraga dan kesehatan $1 \times 140$ menit dan $2 \times 70$ menit terhadap tingkat kebugaran dan efektifitas waktu pembelajaran siswa di kelas V MI Bahrul Ulum Sukodono Sidoarjo.Subyek dalam penelitian ini yaitu seluruh kelas $V$ yang berjumlah 44 siswa. Hasil dari penelitian ini menunjukkan bahwa terdapat pengaruh waktu pembelajaran pendidikan jasmani olahraga dan kesehatan terhadap tingkat kebugaran siswa di kelas V MI Bahrul Ulum Sukodono Sidoarjo yang dibuktikan dengan nilait hitung $_{\text {dan nilait tabel, atau nilait }}{ }_{\text {hitung }}$ 2,181 >nilait tabel 2,021 dengan kata lain terdapat terdapat perbedaan penerapan waktu dan efektifitas pembelajaran Pendidikan Jasmani, Olahraga dan Kesehatan terhadap peningkatan kebugaran jasmani siswa di Kelas V MI Bahrul Ulum Sukodono Sidoarjo. Dapat disimpulkan bahwa Ha diterima dan Ho ditolak jadi terdapat terdapat perbedaan penerapan waktu dan efektifitas pembelajaran Pendidikan Jasmani, Olahraga dan Kesehatan terhadap peningkatan kebugaran jasmani siswa di Kelas V MI Bahrul Ulum Sukodono Sidoarjo.
\end{abstract}

Kata Kunci: Waktu Pembelajaran PJOK, Kebugaran Jasmani

\section{PENDAHULUAN}

Pendidikan jasmani olahraga dan kesehatan (PJOK) merupakan salah satu kelompok mata pelajaran dalam sistem kurikulum pendidikan nasional di Indonesia. Standar isi untuk satuan pendidikan dasar dan menengah, cakupan materi kelompok mata pelajaran Pendidika Jasmani Olahraga dan Kesehatan (PJOK) dimaksudkan untuk meningkatkan potensi fisik kebugaran serta membudayakan sikap sportif, disiplin, kerjasama, dan hidup sehat (Depdiknas, 2003). Kemudian didalam teknik penilaiannya pembelajaran Pendidikan Jasmani Olahraga dan Kesehatan (PJOK) mengacu pada tiga aspek penilaian yaitu aspek kognitif, afektif, dan psikomotor peserta didik. Melalui pembelajaran Pendidikan Jasmani Olahraga dan Kesehatan (PJOK) yang teratur, terencana, terarah dan terbimbing diharapkan dapat perilaku peserta didik serta dapat mencapai seperangkat tujuan yang meliputi pembinaan dan pembentukan bagi pertumbuhan jasmani peserta didik.
Pendidikan nasional terdapat sebuah kurikulum yang merupakan pedoman seorang guru dalam melaksanakan pembelajaran. Kurikulum adalah rancangan pendidikan yang memberi kesempatan untuk peserta didik mengembangkan potensi dirinya dalam suatu suasana belajar yang menyenangkan dan sesuai dengan kemampuan dirinya untuk memiliki kualitas yang diinginkan masyarakat dan bangsanya. Secara yuridis, kurikulum adalah suatu kebijakan publik yang didasarkan kepada dasar filosofis bangsa dan keputusan yuridis di bidang pendidikan (Kementerian Pendidikan Dan Kebudayaan, 2016). Di Indonesia sendiri sudah berkembang dengan masalah kurikulum yang sekarang sudah memakai Kurikulum 2013. Kurikulum 2013 saat ini diharap mampu menjawab permasalahan pendidikan nasional dan untuk mengarah pada perbaikan sistem pendidikan demi menciptakan generasi masa depan berkarakter, yang memahami jati diri bangsanya dan menciptakan anak yang unggul, mampu bersaing di dunia 
Jurnal Kejaora: Jurnal Kesehatan Jasmani dan Olah Raga

ISSN: 2541-5042 (Online)

ISSN: 2503-2976 (Print)

Volume 5 Nomor 2, Edisi November 2020

internasional (Sofyan, 2019). Sedangkan dalam kurikulum Pendidikan Jasmani Olahraga dan Kesehatan (PJOK) memiliki tujuan yaitu untuk meningkatkan kebugaran jasmani peserta didik.

Salah satu sasaran pembelajaran Pendidikan Jasmani Olahraga dan Kesehatan (PJOK) yang tercantum dalam PP No. 19 Tahun 2005 tentang Standar Kompetensi Lulusan adalah kebugaran jasmani. Tujuan mata pelajaran PJOK untuk meningkatkan kebugaran jasmani peserta didik diamanahkan disemua jenis dan jenjang pendidikakan. Setiap kali membicarakan tentang masalah kualitas kejasmanian tidak dapat terlepas dari kebugaran jasmani yang dalam Bahasa internasionalnya disebut dengan Physical fitness. Kebugaran jasmani adalah kemampuan tubuh seseorang untuk melakukan tugas pekerjaan sehari-hari tanpa menimbulakan kelelahan yang berarti (Santoso, 2016). Kesegaran jasmani meliputi keadaan sehat jasmani dan kemampuan kerja secara efisien tanpa menimbulkan kelelahan yang berarti (Fikri, 2018). Adapun seseorang yang bugar dalam kaitannya olahraga dan aktivitas fisik diartikan sebagai orang yang mampu menjalankan kehidupan sehari-hari tanpa melampaui batas daya tahan stress pada tubuh dan memiliki tubuh yang sehat serta tidak beresiko mengalami penyakit yang disebabkan tingkat kebugaran atau kurangnya aktivitas.

Untuk memprediksi kebugaran jasmani seseorang dapat dilakukan melalui tes lapangan (field test) yang menuntut untuk kerja (performance) maksimal peserta tes (Mahardika, 2018). Hasil tes akan menunjukkan prediksi yang akurat jika peserta tes benar-benar menampilkan kemampuan maksimalnya sesuai dengan protocol masing-masing tes. Pendidik dapat memilih jenis tes kebugaran jasmani yang dianggapnya paling baik dan fisibel untuk dilaksanakan. Misalnya tes Balke, Monteye, Havard, Cooper, TKJI, MFT dan lain-lain

Pendidikan Sekolah Dasar khususnya MI (Madrasah Ibtidaiyah) pembelajaran Pendidikan Jasmani Olahraga dan Kesehatan (PJOK) jauh dari tujuan kurikulum pembelajarannya untuk meningkatkan kebugaran peserta didik dikarenakan waktu

sendiri kalah dengan pembelajaran agama yang di atur oleh Yayasan, sehingga seseorang Guru Pendidikan Jasmani Olahraga dan Kesehatan (PJOK) tidak dapat berbuat apa-apa dalam masalah ini. Sebelumnya alokasi waktu $4 \times 35$ menit dalam seminggu dikurangi 1 jam pembelajaran untuk Baca Tulis Al Quran (BTQ). Jadi untuk mengetahui seberapa besar pengaruh dan membuktikkan metode apa yang dapat meningkatkan kebugaran peserta didik dengan alokasi yang minim. Berdasarkan pengalaman dan hasil observasi yang kami lakukan pada kegiatan proses pembelajaran Siswa MI Bahrul Ulum Sukodono Sidoarjo, maka peneliti tertarik untuk mengkaji tentang perbedaan penerapan pembelajaran ditinjau dari segi waktu dalam proses pembelajaran. Dengan demikian tema yang diangkat dalam penelitian ini adalah "Pengaruh Waktu Pembelajaran Pendidikan Jasmani Olahraga dan Kesehatan (PJOK) Terhadap Tingkat Kebugaran Siswa di kelas V MI Bahrul Ulum Sukodono Sidoarjo".

\section{METODE}

Jenis penelitian yang digunakan dalam kegiatan penelitian yaitu eksperimen semu, dimana rancangan penelitian eksperimennya yang lebi tinggi kualitas kontrolnya dibandingkan dengan rancangan penelitian pra-eksperimen (Maksum, 2012). Populasi penelitian yaitu siswa MI Bahrul Ulum Sukodono Sidoarjo Kelas $V$ yang berjumlah 44 Siswa. Sedangkan teknik pengambilan sampel yang digunakan yaitu purposive sampling yang dibagi menjadi dua dengan masing-masing berjumlah 22 siswa.

Instrumen yang digunakan dalam memperoleh data yaitu Tes Kebugaran Jasmani Indonesia (TKJI). Sedangkan teknik analisis data yaitu menggunakan analisis uji t sebagai cara untuk mengetahui hasil kebugaran siswa.

\section{HASIL DAN PEMBAHASAN}

Berdasarkan hasil perhitungan analisis dalam penelitian ini dapat ditampilkan dalam tabel di bawah ini: 
Jurnal Kejaora: Jurnal Kesehatan Jasmani dan Olah Raga

ISSN: 2541-5042 (Online)

ISSN: 2503-2976 (Print)

Volume 5 Nomor 2, Edisi November 2020

Tabel 1. Waktu Pembelajaran 1 x 140 Menit

\begin{tabular}{lccl}
\hline Thitung & $\mathrm{T}_{\text {tabel }}$ & $\begin{array}{l}\text { Sig (2- } \\
\text { tailed) }\end{array}$ & Peningkatan \\
\hline 13,748 & 1,721 & 0,000 & $46 \%$ \\
\hline
\end{tabular}

Berdasarkan tabel 1 di atas dapat dijelaskan bahwa nilai thitung lebih besar daripada nilai $t_{\text {tabel }}$ yaitu $13,748>1,721$. Nilai sig juga lebih kecil daripada 0,05 yaitu 0,000 . Dengan prosetase peningkatan $46 \%$.

Tabel 2. Waktu Pembelajaran $2 \times 70$ Menit

\begin{tabular}{llll}
\hline$T_{\text {hitung }}$ & $\mathrm{T}_{\text {tabel }}$ & $\begin{array}{l}\text { Sig (2- } \\
\text { tailed) }\end{array}$ & Peningkatan \\
\hline 15,945 & 1,721 & 0,000 & $59 \%$ \\
\hline
\end{tabular}

Berdasarkan tabel 2 di atas dapat dijelaskan bahwa nilai thitung lebih besar daripada nilai $t_{\text {tabel }}$ yaitu $15,945>1,721$. Nilai sig juga lebih kecil daripada 0,05 yaitu 0,000 . Dengan prosetase peningkatan $59 \%$.

Tabel 3. Perbandingan Waktu Pembelajaran $1 \mathrm{x}$ 140 dengan 2 x 70 Menit

\begin{tabular}{lll}
\hline$T_{\text {hitung }}$ & $\mathrm{T}_{\text {tabel }}$ & Sig (2-tailed) \\
\hline 2,181 & 2,021 & 0,035 \\
\hline
\end{tabular}

Berdasarkan tabel 3 di atas dapat dijelaskan bahwa nilai thitung lebih besar daripada nilai $t_{\text {tabel }}$ yaitu $2,181>2,021$. Nilai sig juga lebih kecil daripada 0,05 yaitu 0,035.

Kondisi kebugaran jasmani dan perilaku hidup aktif yang sudah terpuruk akibat kemajuan teknologi diperparah lagi oleh kondisi pembelajaran pendidikan jasmani yang kurang efektif. Guru sebagai sumber utama dalam proses pembelajaran di SD memiliki tanggung jawab paling besar dalam upaya mengefektifkan pembelajaran. Efektivitas pembelajaran pendidikan jasmani tercermin dalam keterlibatan siswa selama dan setelah pembelajaran itu berakhir (Saputra, 2011). Kondisi tersebut selain menyebabkan kurangnya kesempatan anak melakukan aktivitas fisik dalam pendidikan jasmani, juga menyebabkan banyak guru pendidikan jasmani tidak mampu mencapai tujuan pendidikan jasmani (Sugiarto, 2015).

$\mathrm{Hal}$ ini yang penulis anggap kurang efektif, karena pelaksanaan Pendidikan jasmani seminggu satu kali kemungkinan besar tujuan yang berhubungan dengan pengembangan kesegaran jasmani tidak bisa

tercapai. Frekuensi olahraga dengan frekuensi sering yaitu sama dengan atau lebih dari 3 kali seminggu sebagian besar mempunyai indeks kebugaran kategori sedang (Nurfadli et al., 2015). Dengan kata lain, pendidikan jasmani akan dapat dirasakan manfaatnya apabila frekuensi aktivitas fisik minimal 3 kali dalam seminggu dengan lamanya aktivitas 30 menit atau lebih.

Berdasarkan kenyataan tersebut efektivitas penyelenggaraan kurikulum pendidikan jasmani jelas masih tergolong rendah, apa yang dapat diharapkan dari pembelajaran pendidikan jasmani, materi (bahan ajar) yang banyak yang ada dalam kurikulum terlalu sulit untuk dilaksanakan dengan alokasi waktu yang hanya 1 minggu satu kali. Hasil penelitian yang diperoleh adalah efektivitas waktu pembelajaran PJOK pada guru 100 menit dengan persentase $83 \%$ (Kusuma \& Winarno, 2018). Dengan kata lain terbatasnya waktu menyebabkan programprogram pendidikan jasmani di sekolah termarginalkan yang berujung pada rendahnya aktivitas fisik yang dilakukan para siswa dalam pendidikan jasmani yang diajarkan di sekolah.

Oleh karena itu, program kebugaran jasmani yang realistik untuk situasi seperti ini perlu dipertimbangkan. Untuk mengatasi permasalahan tersebut, perlu adanya pendistribusian waktu yang dapat meningkatkan frekuensi dan intensitas aktivitas fisik dalam pembelajaran pendidikan jasmani di sekolah. Pandangan penulis, perubahan pelaksanaan pembelajaran pendidikan jasmani dari 1 kali per minggu dengan waktu $4 \times 35$ menit atau 140 menit, menjadi 2 kali pertemuan per minggu dengan waktu 70 menit per tatap muka merupakan jalan keluar dari permasalahan kurangnya aktivitas fisik dan menurunnya tingkat kebugaran jasmani siswa.

\section{KESIMPULAN}

Berdasarkan hasil temuan yang telah dipaparkan, maka dapat disimpulkan bahwa terdapat perbedaan yang paling dominan pada waktu pembelajaran Pendidikan Jasmani, Olahraga dan Kesehatan terhadap peningkatan kebugaran jasmani siswa. Bahwa waktu pembelajaran yang sangat 
Jurnal Kejaora: Jurnal Kesehatan Jasmani dan Olah Raga

ISSN: 2541-5042 (Online)

ISSN: 2503-2976 (Print)

Volume 5 Nomor 2, Edisi November 2020

dominan diterapkan untuk peningkatan kebugaran siswa yaitu pembalajaran PJOK dilakukan $2 \times 70$ menit atau 1 pertemuan 70 menit dalam 1 hari.

\section{DAFTAR PUSTAKA}

Depdiknas. (2003). Kurikulum 2004; Standar Kompetensi Matapelajaran Pendidikan Jasmani SD dan MI. Jakarta: Balitbang Depdiknas.

Fikri, A. (2018). Studi Tentang Tingkat Kesegaran Jasmani Mahasiswa Penjaskes STKIP PGRI Lubuklinggau. Gelanggang Olahraga: Jurnal Pendidikan Jasmani Dan Olahraga (JPJO), 14), 74-83. https://doi.org/10.31539/jpjo.v1i2.135

Kementerian Pendidikan Dan Kebudayaan. (2016). Dokumen Kurikulum 2013. In Kementerian Pendidikan Dan Kebudayaan (Issue Desember).

Kusuma, R. A., \& Winarno, M. E. (2018). Efektivitas Waktu Pembelajaran Pendidikan Jasmani Olahraga dan Kesehatan di SMPN 11 Malang. Gelanggang Pendidikan Jasmani Indonesia, 2(2), 135. https://doi.org/10.17977/um040v2i2p13 5-141

Mahardika, I. M. S. (2018). Pengantar Evaluasi Pengajaran. Surabaya: Unesa University Press.

Maksum, A. (2012). Metodologi Penelitihan Dalam Olahraga. Surabaya: Universitas Negeri Surabaya University Press.

Nurfadli, R. R., Jayanti, S., \& Suroto. (2015). Hubungan Indeks Massa Tubuh Dan Frekuensi Olahraga Terhadap Kebugaran Jasmani Pekerja Konstruksi Di PT. PP (PERSERO) TBK TBK Proyek Apartemen Pinnacle Semarang Pinnacle Semarang. Jurnal Kesehatan Masyarakat (e-Journal), 3(1), 445-453.

Santoso, D. A. (2016). Analisis Tingkat Kebugaran Jasmani Atlet Bolavoli Putri Universitas Pgri Banyuwangi. Kejaora, 1(1), 37-46.

Saputra, Y. M. (2011). Supervisi Pembelajaran Untuk Meningkatkan Kinerja Guru Pendidikan Jasmani. Jurnal IImu Pendidikan Universitas 